\title{
Biological monitoring of aquatic ecosystems in Italy
}

\author{
Renato BAUDO \\ CNR Istituto Italiano di Idrobiologia, Largo V. Tonolli 50, 28922 Verbania Pallanza, Italy \\ e-mail: r.baudo@iii.to.cnr.it
}

\begin{abstract}
In Italy, Ecotoxicology has found a place with the Legislative Decree n. 152 (May 11, 1999), emanated in fulfilment of the Directives 91/271/CEE "urban waste-water treatment" and 91/676/CEE "protection of waters against pollution caused by nitrates from agricultural sources". This decree in reality goes beyond (actually anticipating the content of the Framework Directive on Water, still under way of elaboration), and charges the Regions with the duty to identify, for all and each water body, the class of quality on the basis of a chemical and biological monitoring and their classification according to the environmental quality objectives. To this aim, for all water bodies (lakes, rivers, groundwater, coastal waters) the ecological, chemical, and environmental status must be assessed by measuring specific parameters. This paper briefly summarises the role of biological monitoring in the classification of waters in five different categories, ranking from High to Foul Environmental status.
\end{abstract}

Key words: Italian law on water, ecotoxicology, biotic index, toxicity testing, lakes and river classification

\section{INTRODUCTION}

The management of water resources in Italy since very recently has been based almost completely on the monitoring of the chemical characteristics of industrial and urban effluents, and to a lesser extent on the chemical monitoring of the receiving water bodies. This approach, ignoring the biotic components, of course in many cases failed to adequately protect the aquatic environments. Hence, wishing to improve the tools needed to control the environmental pollution, it became necessary to implement the chemical monitoring with some sort of biological monitoring. This is exactly the field of Ecotoxicology, defined as the science of the effects of poisons on the ecosystems (Moriarty 1983).

In brief, ecotoxicological concepts, principles, and methods can be employed either before or after a pollution event may take place:

- before, to forecast the possible undesirable effects on environment due to the input of a single chemical (i.e., marketing of new products) or a mixture of chemicals, at least part of which are potentially toxic (i.e., waste waters and industrial effluents). In this case, a number of different tests may be employed for the Toxicity Evaluation of the potential toxicant(s);

- after, to assess the undesired effects produced, or being produced, into the environment by the introduction of a single chemical or a mixture of chemicals, part of which potentially toxic, considering the physical, chemical, and biological interactions with the different abiotic components of the environment itself. The ecotoxicological approach, therefore, here relies principally on the Biomonitoring and the Toxicity Identification and Evaluation (TIE).
In both cases, Ecotoxicology hence concentrates on the responses of biological organisms.

In the water management, the quality of a resource must be assessed, and then checked again from time to time, on a routine basis. This means that Ecotoxicology must be called in, specifically to conduct the so-called "Biological monitoring" (AAVV 1979; Moriarty,1983; Herricks et al. 1989; Clements 1991; Loeb \& Spacie 1994; Munawar et al. 1995; Bargagli 1998).

This rather broad term actually has been used to indicate three different approaches.

1. The study of the biology of the exposed organisms, aiming to detect adverse effects which could indicate exposition to toxic levels of chemicals in the environment.

2. The comparison of the concentrations in selected fluids or tissues with reference limits (not to be overcome to avoid adverse effects).

3. The measurement of biological parameter (biomarkers) which are related to the exposition to toxic chemicals.

The first (Ford 1989; Levine 1989; Weinstein \& Birk 1989; Coler \& Rockwood 1989; Henry \& Atchinson, 1991; Ghetti 1997) addresses the community composition (number of species, relative abundance, indicators species, richness, diversity, evenness, or biotic indexes), taking into accounts the epidemiology (pathologies, parasitism, malformations, tumoral forms, ...) and the behaviour (avoidance reaction, reproductive behaviour, ...) of the inhabitants of the investigated site.

The second approach (Beeby 1991; Newman \& Heagler 1991; Matis et al. 1991; ECETOC 1995; Vighi \& Calamari 1996; Bargagli 1998) makes use of the socalled "Bioindicators", that is organisms that pick up the toxicants from their environment in different ways. 
More precisely, the studies of this kind aim to assess:

- bioconcentration from water (the most known examples are metals in mosses and lichens);

- bioaccumulation from water, air, soil, food (as in the "Mussel watch", which measures the pollutant concentrations in molluscs);

- biomagnification through the food web (such as the accumulation of $\mathrm{Hg}$ in pikes, or DDT in fish eating birds).

The third ecotoxicological approach (Foulkes 1982; Klaverkamp et al. 1991; Malins \& Ostrander 1994; Munawar et al. 1995) is based on the detection of:

- specific biochemical indicators (i.e., cytochrome P450 monooxygenase induction, indicating an exposure to organic pollutants; inhibition of erythrocyte delta-aminolevulinic acid dehydrase, as the result of $\mathrm{Pb}$ exposure; metallothionein synthesis in liver/kidneys, after a metal exposure; lipid peroxidation, for the reactive oxygen action on polyunsaturated fatty acids in cell membranes);

- non-specific biochemical indicators (endocrine responses resulting from alterations of release of catecholamines and corticosteroid hormones; reproductive responses after alterations of reproductive steroid hormones);

- molecular responses (gene expression, DNA adduct formation, DNA strand breakage, due to carcinogenic and genotoxic compounds).

Some of these ecotoxicological methods seem to have found a place in Italy with the Legislative Decree n. 152 (May 11, 1999).

\section{LEGISLATIVE DECREE N. 152 (MAY 11, 1999)}

This decree, intended to fulfil the Directives 91/271/CEE "urban waste-water treatment" and 91/676/CEE "protection of waters against pollution caused by nitrates from agricultural sources", in reality goes beyond and actually anticipates the content of the Framework Directive on Water, still under way of elaboration. In fact, the decree amends all previous laws regarding effluents, drinking waters, bathing waters, waters suitable for fish life, or suitable for molluscs, and so on, and charges the Regions with the duty to identify, for all and each water body, the class of quality on the basis of a monitoring and their classification according to the environmental quality objectives. These environmental quality objectives state that, for all surface waters, the ecological, chemical, and environmental status be assessed.

The Ecological status is described by: the basic physical and chemical parameters related to the oxygen balance and trophic state; the Extended Biotic Index (for running waters); some biological assessment (the suitable methods, not yet available, will be established by the Italian National Environmental Protection Agency,
ANPA). The Chemical status depends on the presence of micropollutants or dangerous chemicals. Their threshold levels are calculated from the LC50 or EC50 values, measured for 3 trophic levels. Further studies on sediments and effects complement the chemical data, but again the pertaining methodology has yet to be prescribed by ANPA. The Environmental status (describing the "departure from a reference water body") will then be estimated by combining the previous two indicators.

For surface waters, the Environmental status ranks from High to Foul in the following way.

- High - No or minimal chemical/physical alterations; biological quality equal or very close to a reference ecotype; micropollutants concentrations similar to background values.

- Good - Biological quality only slightly different from a reference ecotype; micropollutants concentrations producing no short- and long term effect.

- Sufficient - Biological quality moderately different from a reference ecotype; micropollutants concentrations producing no short- and long term effect.

- Poor - Biological quality noticeably different from a reference ecotype; micropollutants concentrations producing medium- and long term effect.

- Foul - Severe departure of biological quality from a reference ecotype; producing severe short- and long term effect.

The weak point of this classification obviously is the continuous reference to the quality of a "reference ecotype", that has to be identified, possibly even on a theoretic basis. Considering the large variability of climate and geology of the Italian peninsula, it will be very interesting to see in the coming years how this crucial problem will be solved.

Another questionable criteria is the one that establishes that, after an exploratory phase (to be completed by the end of the year 2001), if a water body attains High or Good Environmental status, the controls in the following phase will be based only on the chemical monitoring. This is obviously a non-sense from the ecotoxicological point of view, since the chemical analysis necessarily covers only a limited number of parameters, and only the control of the biological community itself can assure that the environmental status is really keeping in good conditions.

For groundwater, there will be no such a problem. The decree in fact for these waters states that the Environmental status can be assessed on the basis of the chemical analyses only. For running waters, the role of biota is recognised insofar the Extended Biotic Index (that in the Italian version is called IBE, Ghetti 1997) is foreseen.

In addition, but only on a facultative basis, biological assays for short- and long term effects may also be performed, with the highest preference given to toxicity test with concentrated water samples on Daphnia magna; mutagenicity and teratogenicity tests on con- 
centrated water samples; algal assay; bioluminescent bacteria test with concentrated water samples. Furthermore, it is advisable to evaluate the bioaccumulation of primary pollutants (PCB, DDT, and Cd) on muscle tissue from resident fish or macrobenthos.

Also the sediment may be studied, first at all for the chemistry ( $\mathrm{As}, \mathrm{Cd}, \mathrm{Zn}$, Total $\mathrm{Cr}, \mathrm{Hg}, \mathrm{Ni}, \mathrm{Pb}, \mathrm{Cu}$, organic micropollutants such as PAHs, PCBs, dioxins, ...); only "if needed", tests on extracts, pore water, or whole sediments may be done (with the highest priority given to chronic and sub-chronic tests with Oncorhynchus mykiss, Daphnia magna, Ceriodaphnia dubia, Chironomus tentans and $C$. riparius, Pseudokirchneriella subcapitata (ex Selenastrum capricornutus) and bioluminescent bacteria).

For the resulting watercourse classification, the Environmental status will be defined combining the indication on the Ecological status (IBE + macrodescriptors: 6 chemical parameters plus Escherichia coli) and on the Chemical status (checking whether the pollutant concentrations are below or above the threshold limits).

Therefore, the only ecotoxicological data of interest is the Extended Biotic Index. However, if the Environmental status is lower than Good, and especially if IBE is worst than macrodescriptors, further analyses, toxicity tests and studies of accumulation in sediments or biota are requested. If any sign of toxicity and/or bioaccumulation is detected, the Environmental status will automatically ranked as Poor. For lakes, the basic evaluation depends on 13 physico-chemical parameters, plus chlorophyll. Organic and inorganic micropollutants are regarded only as "additional parameters".

The lake classification therefore will be based on the Ecological status (transparency, hypolimnetic oxygen, chlorophyll- $a$, total phosphorus), and as usual on the verification whether the concentrations of a selected number of pollutants are below the threshold limits.

As for rivers, only if the Environmental status is lower than Good further studies on toxicity and accumulation are requested. If detected, the lake Environmental status will be declared Poor.

For coastal seawaters the decree foresees a more complex monitoring, starting with the measurements:

- on water, of several basic parameters (11 physicochemical parameters + enterococcus + chlorophyll);

- on sediments, of grain size, PAHs, bioaccumulable heavy metals, organic $\mathrm{C}$, PCBs and pesticides, biological tests on different taxonomic groups;

- on biota, of metal and organic pollutant (PAHs, PCBs and pesticides) bioaccumulation in bivalves Mytilidae (Mytilus galloprovincialis) or Ostreoidea (Ostrea edulis, Crassostrea gigas). If these species are unavailable, Telloidea (Donax trunculus) and Veroidea (Tapes decussata, Tapes philippinarum) should be preferred. Furthermore, additional investigation should be done on special biocoenoses (aquatic plants, corals, ...), as well as short- and long-term tests, with different taxonomic groups (preference being given to autochthonous species and standardised protocols).

Therefore, the coastal seawater classification will be based on the Trophic Index (chlorophyll- $a$, dissolved oxygen, total phosphorus, nitrogen), and on the Environmental quality status, thus defined.

- High - fair transparency, no abnormal colours, no benthic oxygen under saturation.

- Good - occasional turbidity, occasional abnormal colours, occasional benthic oxygen under saturation.

- Poor - poor transparency, abnormal colours, occasional benthic oxygen under saturation or hypoxia, suffering benthic ecosystem.

- Shoddy - high turbidity, diffuse and persistent abnormal colours, diffuse and persistent benthic oxygen hypoxia/hypoxia, benthos kills, alteration/simplification the benthic communities, economic damage to tourism fisheries and aquaculture.

But, again in the case of coastal waters, if the tests proved some toxicity and/or bioaccumulation, the Environmental status will be automatically ranked as Poor. For effluents discharging in surface waters or sewers, the prescribed analyses will cover 49 physico-chemical parameters, Escherichia coli, and acute toxicity testing (LC50 or LC80 $24 \mathrm{~h}$ with Daphnia magna). Only facultative: acute toxicity testing with Ceriodaphnia dubia, Pseudokirchneriella subcapitata, bioluminescent bacteria, Artemia salina, or other (protocols to be established by ANPA). When the effluents are directly discharged on the soil, the measurement of 37 physico-chemical parameters, Escherichia coli, and acute toxicity (LC50 24 $\mathrm{h}$ with Daphnia magna) is mandatory, while additional tests may be required as for effluents discharging in waters. For all effluents, when more tests are performed, the worst result will be considered. However, even when toxicity will be detected, there will be no penalty, but only the obligation to do further studies and to perform a Toxicity Identification Evaluation, aiming to the removal of the toxicity cause.

\section{CONCLUSIONS}

At long last, it seems that even Italy has discovered Ecotoxicology or, better, its potential "official" use. However, in most cases it is only secondary to the chemical indication. In synthesis, the biological monitoring of the first type (inventory of the community, relative abundance, indicators species) is adopted on a routine basis only for running waters (but a refinements is needed, due to the large Italian North-South, and East-West differences).

For lakes, "reference ecotypes" must be devised, before this kind of monitoring could be used. No room is made for epidemiological or behavioural studies.

The biological monitoring of type 2 (bioaccumulation) is foreseen only when a previous knowledge al- 
ready indicates that the environment could be compromised.

Finally, the biological monitoring of type 3 (biomarkers) at the moment is completely ignored. However, since for almost all tests the methodological protocols have to be prepared by the National Environmental Agency, hopefully some method will be suggested also for this category (they are surely the best suited to run the TIE investigation).

The approach followed so far clearly reflect the dated concept that biological data, being so variable, are only good to support the indication gathered from the more precise chemical analyses. Anyway, it is the first step towards a better appreciation of the ecotoxicological tests. Moreover, with the application of the decree, many more scientists will have to learn how to do them. Therefore, in the coming years the widespread use of the biological monitoring will surely improve the knowledge of the status of the Italian waters.

\section{REFERENCES}

AAVV. 1979. Animals as Monitors of Environmental Pollutants. U.S. National Academy of Sciences: $421 \mathrm{pp}$.

Bargagli, R. 1998. Trace Elements in Terrestrial Plants. An Ecophysiological Approach to Biomonitoring and Biorecovery. Springer: $324 \mathrm{pp}$.

Beeby, A. 1991. Toxic Metal Uptake and Essential Metal Regulation in Terrestrial Invertebrates: A Review. In: M.C. Newman \& A.W. McIntosh (Eds), Metal Ecotoxicology. Concepts \& Applications. Lewis Publ.: 65-89.

Clements, W.H. 1991. Community Responses of Stream Organisms to Heavy Metals: A Review of Observational and Experimental Approaches. In: M.C. Newman \& A.W. McIntosh (Eds), Metal Ecotoxicology. Concepts \& Applications. Lewis Publ.: 363-391.

Coler, R.A. \& J.P. Rockwood. 1989. Water Pollution Biology. A Laboratory/Field Handbook. Technomic Publ. Co.: 107 pp.

ECETOC. 1995. The Role of Bioaccumulation in Environmental Risk Assessment: The Aquatic Environment and Related Food Webs. ECETOC: 128 pp.

Ford, J. 1989. The effects of chemical stress on aquatic species composition and community structure. In: S.A. Levin, M.A. Harwell, J.R. Kelly \& K.D. Kimball (Eds), Ecotoxicology: Problems and Approaches. Springer-Verlag: 99144
Foulkes, E.C. (Ed.). 1982. Biological Roles of Metallothionein. Elsevier: 327 pp.

Ghetti, P.F. 1997. Indice Biotico Esteso (I.B.E.). I macroinvertebrati nel controllo della qualità degli ambienti di acque correnti. Provincia Autonoma di Trento: $222 \mathrm{pp}$.

Henry, M.G. \& G.J. Atchinson. 1991. Metal Effects on Fish Behavior - Advances in Determining the Ecological Significance of Responses. In: M.C. Newman \& A.W. McIntosh (Eds), Metal Ecotoxicology. Concepts \& Applications. Lewis Publ.: 131-143.

Herricks, E.E., D.J. Schaeffer \& J.A. Perry. 1989. Biomonitoring: closing the loop in the environmental sciences. In: S.A. Levin, M.A. Harwell, J.R. Kelly \& K.D. Kimball (Eds), Ecotoxicology: Problems and Approaches. Springer-Verlag: 351-366.

Klaverkamp, J.F., M.C. Dutton, H.S. Majewski, R.V. Hunt \& L.J. Wesson. 1991. Evaluating the Effectiveness of Metal Pollution Controls in a Smelter by Using Metallothionein and Other Biochemical Responses. In: M.C. Newman \& A.W. McIntosh (Eds), Metal Ecotoxicology. Concepts \& Applications. Lewis Publ.: 33-64.

Levine, S. N. 1989. Theoretical and methodological reasons for variability in responses of aquatic ecosystem processes to chemical stresses. In: S.A. Levin, M.A. Harwell, J.R. Kelly \& K.D. Kimball (Eds), Ecotoxicology: Problems and Approaches. Springer-Verlag: 145-179.

Loeb, S.L. \& A. Spacie (Eds). 1994. Biological monitoring of aquatic systems. Lewis Publ.: 381 pp.

Malins, D.C. \& G.K. Ostrander (Eds). 1994. Aquatic Toxicology. Molecular, Biochemical and Cellular Perpectives. Lewis Publ.: 539 pp.

Matis, J.H., T.H. Miller \& D.M. Allen. 1991. Stochastic Models of Bioaccumulation. In: M.C. Newman \& A.W. McIntosh (Eds), Metal Ecotoxicology. Concepts \& Applications. Lewis Publ.: 171-206.

Moriarty, F. 1983. Ecotoxicology. The Study of Pollutants in Ecosystems. Academic Press: 289 pp.

Munawar, M., O. Hänninen, S. Roy, N. Munawar, L. Kärenlampi \& D. Brown. 1995. Bioindicators of environmental health. SBP Academic Publ.: $265 \mathrm{pp}$.

Newman, M.C. \& M.G. Heagler. 1991. Allometry of Metal Bioaccumulation and Toxicity. In: M.C. Newman \& A.W. McIntosh (Eds), Metal Ecotoxicology. Concepts \& Applications. Lewis Publ.: 91-130.

Vighi, M. \& S. Calamari. 1996. Indici e scale di impatto ecotossicologico. In: R. Vismara \& A. Zavatti (Eds), Indicatori e scale di qualità. Pitagora Editrice Bologna: 353-364.

Weinstein, D.A. \& E.M. Birk. 1989. The effects of chemicals on the structure of terrestrial ecosystems: mechanisms and patterns of change. In: S.A. Levin, M.A. Harwell, J.R. Kelly \& K.D. Kimball (Eds), Ecotoxicology: Problems and Approaches. Springer-Verlag: 181-209. 